\title{
Disorders of carbohydrate metabolism in experimental brain injury
}

\author{
S.V. Ziablitsev, S.V. Pishchulina, S.V. Kolesnikova, R.N. Boris, Ya.S. Yuzkiv \\ Bogomolets National Medical University, Kyiv, e-mail: zsv1965@gmail.com
}

\begin{abstract}
In experimental heavy closed brain injury (mortality in five days - 86\%) it is shown that from the first hours the violations of carbohydrate metabolism in the form of triad were formed: the marked hyperglycemia (3.33.6 times), hyperinsulinemia (2.4-3.2 times) and insulin resistance (HOMA-indexes increased to 8.0-11.7 times). These changes were caused by a decrease in tissue sensitivity to insulin and were accompanied by decrease in functional activity of the pancreatic $\beta$-cells. In total it is possible to consider these changes as a pentad of the typical disorders of carbohydrate metabolism at brain injury.

Key words: brain injury; glucose; insulin; violations of carbohydrate metabolism.
\end{abstract}

\section{INTRODUCTION}

Rate of anthropogenic disasters is increasing and cerebral trauma is one of important reasons of mortality [1-3]. Tissue damage and cellular disorders are observed as a result of brain injury: edema, intracranial hemorrhage, hematoma, axonal destruction [4, 5]. Disorders of circulation, immunosuppression, accumulation of toxins, metabolic disturbances worsen clinical course $[6,7]$. Posttraumatic axonal injury is caused by increased proteolysis, expression of calpain mRNA, disorders of retrograde axonal transport [8, 9]. Neuroendocrine system is affected too. Pathochemical disorders of brain next: total intensification of metabolism $\rightarrow$ formation of energy deficiency $\rightarrow$ development of cellular intoxication $\rightarrow$ formation of secondary structural disorders [10]. The hypermetabolic syndrome develops in different extremal states and in patients with cerebral trauma also [11]. Secretion of catecholamines, glucocorticoids and angiotensin is stimulated by trauma and stress [12]. Oxygen necessity of brain increase, but disorders of circulation, accumulation of lactate, formation of acidosis lead to hypoxia [13]. Activation of glycolysis and gluconeogenesis, formation of tissue tolerance to insulin, hyper- glycemia are observed [14, 15]. Level of hyperglycemia correlate with severity of injury [16]. Brain is insulin-independent tissue, glucose entry to neurons is implemented by transporters GLUT-1, GLUT-3 and GLUT-5, therefore brain is more sensitive to hypoglycemia and hypoxia, than are organs [17, 18]. Hyperactivation of central regulatory systems is first non-specific reaction of the body after some hours of brain injury, a rise in adrenocorticotropic hormone, corticosterone, vasopressin and insulin has been found. The research investigates the carbohydrate metabolism in experimental brain injury.

\section{METHODS}

Experiment was made on 75 white males' rats with $195 \pm 10 \mathrm{~g}$ weight. Brain injury was modeled by one stroke on cranium. Lethality was $86 \%$ during first five days after trauma. Preparation animals to experiment, anesthesia and vivisection were made according to European Convention for Protection of Animals (Strasbourg, 1986). Control group included 15 animals. Examination of animals after trauma showed presents of subperiosteal, subdural and epidural haematomas, brain crushing area and detritus, edema. Therefore animals had moderate closed

(C) S.V. Ziablitsev, S.V. Pishchulina, S.V. Kolesnikova, R.N. Boris, Ya.S. Yuzkiv 
cerebral injury with undisplaced skull fracture. Levels of glucose and insulin in the blood were examined after 3, 24, 48 and 72 hours after trauma. Neurological deficiency was examined by Todd number (1981) in L.A. Shalyakin (1987) and A.Y. Eutoshenko (1989) modification [14].

Concentration of hormones was made by immunoassay method. Indexes of insulin resistance (HOMA-IP), function of $\beta$-cells (HOMA$\beta$-cells) and sensitiveness for insulin (QUICKI) were calculated by next formulas:

$$
\begin{gathered}
\text { HOMA-IR }=\frac{\text { glucose }(0) \times \operatorname{insulin}(0)}{22,5}, \\
\text { HOMA- } \beta \text {-cells }=\frac{\text { insulin }(0) \times 20}{(\operatorname{glucose}(0)-3,5)}, \\
\text { QUICKI }=\frac{1}{\lg \text { insulin }(0)+\lg \text { glucose }(0)},
\end{gathered}
$$

where glucose - concentration of glucose in blood (mmol/1), insulin - concentration of insulin in blood (pmol/1). Indexes of insulin resistance, function of $\beta$-cells and sensitiveness for insulin were explored. The study results were processed using the method of multiple comparisons in the program of the statistical analysis MedCalc v.15.11.0 (MedCalc Software bvba, 1993-2015).

\section{RESULTS AND DISCUSSION}

Level of glucose increased after traumatic injury in all periods of investigation (Table 1). Maximal augmentation was observed after 3 and 24 hours after trauma (in 3.7 and 3.3 times, $\mathrm{P}<0.05$ in both cases).

Increased level of glucose after trauma was marked by other writers [14, 15]. This fact was explained by catabolic hormones (catecholamines, glucocorticoids) rising and glycogenolysis and gluconeogenesis activation, first of all in the liver. Launching of this reaction had central disposition, because brain had need of glucose.

At rest the brain uses $60 \%$ of glucose, of which $40 \%$ of glucose is used by $\mathrm{Na}+$ / $\mathrm{K}+\mathrm{ATPase}$ pump. Entrance of glucose is realized by facilitated diffusion with GLUT-3 transporters to neurons and with GLUT-1 to glia cells. This process is independent from insulin concentration in contrast to skeletal muscles, myocardium, fat tissue. Therefore activation of glucose formation by neuroendocrine factors and glucose utilization by brain is powerful defense reaction on traumatic injury. That is way computation of base indexes of influence insulin on glucose level is very important (Table 2).

HOMA-IR (Homeostasis Model Assessment of Insulin Resistance) is most well-known index for determination of insulin efficiency (Mathews et alt., 1985). The higher level of HOMA-IP index insulin accompanied with the lower sensitiveness to insulin and than higher insulin resistance. Disorders of insulin effects are caused by pathological states as a result of abnormal insulin synthesis (pro-receptor level), decrease amount and affinity of receptors (receptor level), reduction molecules of glucose transporter in peripheral tissue GLUT4 (transport of glucose level), disturbances of signal transmission and phosphorilation (postreceptor). The main causes of less sensitivity to insulin are disorders of signal transmission and phosphorilation. The HOMA-IP index increased after 3 hours ten times $(\mathrm{P}<0.05)$ and after 24 hours eight times $(\mathrm{P}<0.05)$ at traumatic period. After that HOMA-IP index decreased gradually, but stayed more, than control level two-three times $(\mathrm{P}<0.05)$ (Table 2$)$. The dynamics of insulin and glucose levels in the blood were same (Table 1 and Figure 1).

Table 1. Levels of glucose and insulin in blood after brain injury $(\mathrm{M} \pm \mathbf{m})$

\begin{tabular}{|l|c|c|c|c|c|c|}
\hline \multirow{2}{*}{ Index } & \multirow{2}{*}{ Control } & \multicolumn{5}{|c|}{ Time after trauma } \\
\cline { 3 - 7 } & & 3 hours & 24 hours & 48 hours & 72 hours & 5 days \\
\hline Glucose, $\mathrm{mmol} / 1$ & $4.93 \pm 0.51$ & $18.12 \pm 1.75^{*}$ & $16.25 \pm 1.08^{*}$ & $7.51 \pm 0.86^{*}$ & $8.94 \pm 0.99^{*}$ & $8.28 \pm 0.81^{*}$ \\
Insulin, $\mathrm{pmol} / \mathrm{l}$ & $18.5 \pm 2.0$ & $58.7 \pm 4.6^{*}$ & $44.9 \pm 3.7^{*}$ & $40.2 \pm 4.1^{*}$ & $28.6 \pm 3.0^{*}$ & $22.8 \pm 2.5$ \\
\hline
\end{tabular}

$* \mathrm{P}<0.05$ in comparison medium level with control group 
Table 2. Dynamics of insulin indexes $(M \pm m)$

\begin{tabular}{|l|c|c|c|c|c|c|}
\hline \multirow{2}{*}{ Index } & \multirow{2}{*}{ Control } & \multicolumn{5}{|c|}{ Time after trauma } \\
\cline { 3 - 7 } & & 3 hours & 24 hours & 48 hours & 72 hours & 5 days \\
\hline HOMA-IR & $4.05 \pm 0.42$ & $47.27 \pm 5.61^{*}$ & $32.43 \pm 3.22^{*}$ & $13.42 \pm 1.84^{*}$ & $11.36 \pm 1.15^{*}$ & $8.39 \pm 0.99^{*}$ \\
HOMA- $\beta$-cells & $258.70 \pm 21.25$ & $80.31 \pm 4.21^{*}$ & $70.42 \pm 5.04^{*}$ & $200.55 \pm 19.57$ & $105.12 \pm 9.85^{*}$ & $95.46 \pm 5.41^{*}$ \\
QUICKI & $0.51 \pm 0.09$ & $0.33 \pm 0.09$ & $0.35 \pm 0.08$ & $0.40 \pm 0.08$ & $0.41 \pm 0.07$ & $0.44 \pm 0.10$ \\
\hline
\end{tabular}

$* \mathrm{P}<0.05$ in comparison medium level with control group

Probable reason of hyperglycemia is a rise of catabolic hormones. Estimation of HOMAIP index dynamics allowed seeing this process in convincing aspect. The level of this index increased ten times after 3 hours after trauma, that is why formation of posttraumatic hyperglycemia was caused by insulin resistance.

Thereby, hyperergic reaction of neurohormonal system with catabolic action generated formation of hyperglycemia at first time after trauma and as a result - formation insulin resistance and hyperinsulinemia such as secondary reaction. These data are confirmed with clinical investigations and experiment revealed that brain injury is accompanied with carbohydrates metabolism disorders: hyperglycemia, hyperinsulinemia and insulin resistance. But there is a question - what is a cause of insulin resistance? More frequent cause of less sensitivity to insulin is disorders of signal transmition and phosphorylation at postreceptor (intracellular)

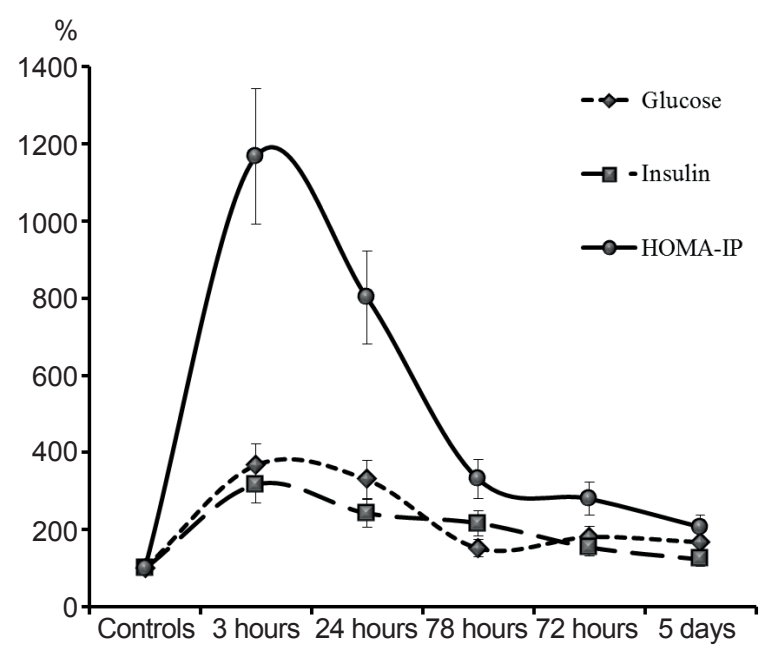

Fig. 1. Glucose, insulin and HOMA-IP index after trauma (the control level is $100 \%$ ) level. Probably, glucocorticoides and catecholamines inhibited phosphorilation of glucose in hexokinase reaction.

Next index is HOMA- $\beta$-cells, this index show function of $\beta$-cells in pancreas. The level of HOMA- $\beta$-cells decreased $-27-41 \%$ from control $(\mathrm{P}<0.05)$, but after 48 hours it increased to $78 \%$, probably, activation of $\beta$-cells in pancreas was a reason. Reduction of HOMA- $\beta$-cells and simultaneous multiple augmentation of insulin in blood are very interesting. Possible explanation is disorders of insulin metabolism by target cells as a result of insulin resistance and accumulation of this hormone in blood. HOMA- $\beta$-cells is calculate such as ratio of insulin level to glycemia, because there is correlation between concentrations of insulin and glucose. Possible causes of normalization of HOMA- $\beta$-cells index are increment of insulin or reduction of glucose.

Period of 48 hours after trauma is critical, the level of glycemia was less in this time, than at other periods, thereby it was a reason return HOMA- $\beta$-cells to norm. Estimation of HOMA$\beta$-cells index revealed mechanisms of disorder of carbohydrate metabolism humoral regulation: posttraumatic hyperglycemia, insulin resistance and hyperinsulinemia are accompanied with functional reduction of $\beta$-cells activity.

Dynamics of sensitivity to insulin at posttraumatic period was analyzed by QUICKI (Quantitative Insulin Sensitivity Check Index). Reduction of QUICKI was observed during all periods of experiment from $64 \%$ after 3 hours after trauma to $86 \%$ after 5 days after trauma. It confirmed, that increment of insulin level is a result of target cells sensitivity reduction and hormone degradation abatement. Pentalogy of 
Cerebral trauma (metabolic imbalance and brain hypoxia)

$$
\downarrow \downarrow \downarrow
$$

Elevation of functional activity of neuroendocrine systems with catabolic effects

(catecholamines and glucocorticoids)

$$
\downarrow \downarrow \downarrow
$$

Carbohydrates metabolism disturbances - inhibition of hexokinase reaction and reduction tissues sensitivity to insulin with hyperinsulinemia

$$
\downarrow \uparrow \downarrow
$$

Formation of hyperglycemia and insulin resistance

$$
\downarrow \uparrow \downarrow
$$

Reduction of functional activity of $\beta$-cells of pancreas

Fig. 2. Interrelation of neurohormonal regulation disorders of carbohydrates metabolism at cerebral trauma

typical carbohydrates metabolism disorders are hyperglycemia, hyperinsulinemia, insulin resistance, reduction of tissues sensitivity to insulin, reduction of functional activity of $\beta$-cells of pancreas (Figure 2).

\section{CONCLUSION}

Disturbances of carbohydrates metabolism are formed from first hours after cerebral trauma: hyperglycemia, hyperinsulinemia and insulin resistance. These changes are caused by reduction tissues sensitivity to insulin and functional activity $\beta$-cells impairment. Thereby, all these reaction formed pentalogy of typical carbohydrates metabolism disorders at cerebral trauma.

\section{С.В. Зябліцев, С.В. Піщуліна, С.В. Колеснікова, Р.М. Борис, Я.С. Юзьків \\ ПОРУШЕННЯ ВУГЛЕВОДНОГО ОБМІНУ ПРИ ЕКСПЕРИМЕНТАЛЬНІЙ ЧЕРЕПНО-МОЗКОВІЙ ТРАВМІ}

В експерименті з моделювання важкої закритої черепномозкової травми (летальність за 5 діб - 86 \%) показано, що вже 3 перших годин формувалися розлади вуглеводного обміну у вигляді тріади типових порушень: виражена гіперглікемія (у 3.3-3.6 раза), гіперінсулінемія (у 2.43.2 раза) та інсулінорезистентність (НОМО-індекс був підвищений в 8.0-11.7 раза). Ці зміни було зумовлено зниженням чутливості тканин до інсуліну, що супроводжувалося пригніченням функціональної активності $\beta$-клітин підшлункової залози. У сукупності це можна було враховувати як пентаду типових порушень вуглеводного обміну при черепно-мозковій травмі.

Ключові слова: черепно-мозкова травма; глюкоза; інсулін; порушення вуглеводного обміну.

Начіональний медичний університет

ім. О.О. Богомольия, Київ, Україна

С.В. Зяблицев, С.В. Пищулина, С.В. Колесникова, Р.Н. Борис, Я.С. Юзькив

\section{НАРУШЕНИЯ УГЛЕВОДНОГО ОБМЕНА ПРИ ЭКСПЕРИМЕНТАЛЬНОЙ ЧЕРЕПНО-МОЗГОВОЙ ТРАВМЕ}

В эксперименте по моделированию тяжелой закрытой черепно-мозговой травмы (летальность за 5 суток $86 \%$ ) показано, что уже с первых часов формировались нарушения углеводного обмена в виде триады типовых нарушений: выраженная гипергликемия (в 3.3-3.6 раза), гиперинсулинемия (в 2.4-3.2 раза) и инсулинорезистентность (НОМА-індекс біл повішен в 8.0-11.7 раза). Эти изменения были обусловлены снижением чувствительности тканей к инсулину и сопровождались подавлением функциональной активности $\beta$-клеток поджелудочной железы, что в совокупности можно было считать пентадой типовых нарушений углеводного обмена при черепно-мозговой травме.

Ключевые слова: черепно-мозговая травма; глюкоза; инсулин; нарушения углеводного обмена.

Национальный медицинский университет

им. А.А. Богомольича, Киев, Украина

\section{REFERENCES}

1. Akang EE, Kuti MA, Osunkoya AO, et al. Pattern of fatal head injuries in Ibadan - a 10 year review. Med Sci Law. 
2002; 42(2). 160-6.

2. Augustine AAdeolu, Orhorhoro OI, Malomo AO, Shokunbi MT. Relationship between injury severity, random blood glucose and management outcome in a cohort of Nigerian patients with head injury. J Neurosci Rural Pract. 2015; 6(2). 216-20. doi: 10.4103/0976-3147.153230 PMCID: PMC4387814.

3. Lu J, Marmarou A, Choi S, et al. Impact and Abic Study Group. Mortality from traumatic brain injury. Acta Neurochir Suppl. 2005; 95. 281-285.

4. Kummer TT, Magnoni S, MacDonald CL, et al. Experimental subarachnoid haemorrhage results in multifocal axonal injury. Brain. 2015; Jun 26. pii: awv180.

5. Werner C, Engelhard K. Pathophysiology of traumatic brain injury. Br J Anaesth. 2007; 99(1). 4-9. doi: 10.1093/bja/ aem131.

6. Liesz A, Roth S, Zorn M, et al. Acquired Immunoglobulin $\mathrm{G}$ deficiency in stroke patients and experimental brain ischemia. Exp Neurol. 2015; 271. 46-52. doi: 10.1016/j. expneurol.2015.04.021.

7. Sahuquillo J, Poca MA, Amoros S. Current aspects of pathophysiology and cell dysfunction after severe head injury. Curr Pharm Des. 2001; 7(15). - 1475-503.

8. Greer JE, McGinn MJ, Povlishock JT. Diffuse traumatic axonal injury in the mouse induces atrophy, c-Jun activation, and axonal outgrowth in the axotomized neuronal population. J Neurosci. 2011; 31. 5089-105. doi: 10.1523/JNEUROSCI.5103-10.2011.

9. Johnson VE, Stewart W, Smith DH. Axonal pathology in traumatic brain injury. Exp Neurol. 2013; 246. 35-43. doi: 10.1016/j.expneurol.2012.01.013.
10. Foley N, Marshall S, Pikul J, et al. Hypermetabolism following moderate to severe traumatic acute brain injury: a systematic review. J Neurotrauma. 2008; 25(12). 141531. doi: 10.1089/neu.2008.0628.

11. Frankenfield D. Energy expenditure and protein requirements after traumatic injury. Nutr Clin Pract. 2006; 21(5). 430-7.

12. Timaru-Kast R, Wyschkon S, Luh C, et al. Delayed inhibition of angiotensin II receptor type 1 reduces secondary brain damage and improves functional recovery after experimental brain trauma. Crit Care Med. 2012; 40(3). 935-44. doi: 10.1097/CCM.0b013e31822f08b9.

13. Andriessen TM, Jacobs B, Vos PE. Clinical characteristics and pathophysiological mechanisms of focal and diffuse traumatic brain injury. J Cell Mol Med. 2010; 14. 2381-92. doi: 10.1111/j.1582-4934.2010.01164.x.

14. Elskyy VN, Ziablitsev SV. Design of brain injury [in Russian]. Donetsk; published by "New world". 2008; 140 p.

15. Liu-DeRyke X, Collingridge DS, Orme J, et al. Clinical impact of early hyperglycemia during acute phase of traumatic brain injury. Neurocrit Care. 2009; 11(2). 151-7. doi: 10.1007/s12028-009-9228-6.

16. Salim A, Hadjizacharia P, Dubose J, et al. Persistent hyperglycemia in severe traumatic brain injury: an independent predictor of outcome. Am Surg. 2009; 75(1). 25-9.

17. McAllister MS, Krizanac-Bengez L, Macchia F, et al. Mechanisms of glucose transport at the blood-brain barrier: an in vitro study. Brain Res. 2001; 904(1). 20-30.

18. McEwen BS, Reagan LP. Glucose transporter expression in the central nervous system: relationship to synaptic function. Eur J Pharmacol. 2004; 490(1-3). 13-24.

Received 03.03.2016 